研究課題別評価

1 研究課題名:

小型超高精度レーザー原子時計の実現

2 研究者氏名: 杉山 和彦

研究員: 御園 雅俊（研究期間 H.15.4 H.16.3）

研究員: Sergey N. Slyusarev（研究期間 H16.5 H.17.10）

3 研究のねらい:

モ一ド同期レーザーは相対位相が決まった多数のモ一ドで同時発振していて、時間軸上では 一定の時間間隔の光パルス列を発生し、超短パルスレーザーとして広く利用されてきた。一方、 周波数軸上でモード同期レーザ一を見た姿は、パルス繰り返し周波数 $f_{\mathrm{rep}}$ だけ正確に周波数の異 なった多数のレーザー光の集合体、いわゆる光周波数コム (comb = 櫛) となっている。モードの 周波数間隔はスペクトル内どこでも $10^{-18}$ 以下で一致していることが実測されていて、光周波数の 優れたマーカーとなる。モード同期レーザーによる光周波数計測技術は、1999 年にドイツ・マック スプランク量子エ学研究所のグループによってその有効性が実証されて以来急速に進歩し、現 在では装置として市販されるまでになった。2005 年にノーベル物理学賞を受賞した 2 人の研究者 の主たる受賞理由にもなっている。

本研究の研究者はまだ初期の時代からこの技術の研究に取り組み、2001 年には我国では初 めて、世界でも 4 グループ目に光周波数計測に成功した。本研究ではこの技術をさらに進めて、 原子等の共鳴周波数にその発振周波数を安定化したレーザーの周波数を、光周波数コムを使っ て正確に分周してマイクロ波周波数標準とする、新しい方式の原子時計を開発する。

この原子時計では基準周波数が光領域になるので、マイクロ波領域の原子の共鳴を基準とす る現在の原子時計よりも周波数安定度が大きく改善される。(同じ大きさの周波数変動ならば、マ イクロ波と光の周波数比だけ、相対的な周波数安定度が改善される。）また、分周の出力となる モ一ド同期レーザーの $f_{\text {rep }}$ は、その位相雑音が通常の発振器よりも小さい。したがって、安定化レ 一ザーへ光分周器をロックする制御帯域よりも速い周波数領域まで含めて、どの周波数領域で評 価しても現在の原子時計の安定度を上回ることができる。基準光周波数は、トラップした単ーイオ ンの共鳴で与えることとした。単一イオンは一度生成すると極めて長時間 (おそらく何ヶ月でも) 保 持することが可能なため、原子時計という装置を目標とする本研究には適している。

本研究では必要となるレーザーを全て半導体レ一ザーとすることで、低消費電力で可搬なシス テムの開発を最終目標とした。現在の周波数標準は、現実には世界中にある 200 台あまりの商 用セシウム原子時計の重み付平均で構成された時系で実現されている。GPS による測地精度も、 衛星に搭載されている原子時計、その多くは商用セシウム時計、により確保されている。レーザー のみを用いた商用の小型原子時計が実現されれば、時系や測地をはじめとして精密計測技術を 高精度化することが可能になる。

4 研究成果:

本研究では(1) 1オクターブ光周波数コムを用いた光分周器、(2) 基準光周波数、(3)半導体レ 一ザーによる光周波数コム、を実現させることを目標とした。(1) ではモ一ド同期チタニウムサファ イア (TiS)レーザーの光パスルをフオトニック結晶ファイバーに導入して確実に1オクターブ光周波 数コムを発生させ、光分周器のプロトタイプを位相同期で実現させることに成功した。(2)では市 販の半導体レーザーを低熱膨張率ガラス製の光共振器の共鳴に高速にロックし線幅を狭窄化し た。長時間の周波数安定化と不確かさの低減をトラップした単ーイッテルビウムイオンの吸収線を 用いて行うこととし、レーザー冷却光源の全半導体レーザー化を進め、イオントラップの動作を確 認した。(3)では DC 電流を流すだけでパルス光を発する自励発振半導体レ一ザーのモ一ド同期 を実現した。注入同期による各モ一ドの線幅狭窄化を行うとその影響で全体のスペクトル幅が狭く なってしまうものの、CW レーザーとのビート信号が高い SN 比で得られ、光周波数コムとして充分 
応用可能なものができた。自励発振半導体レーザーは DVD 読み出し用に開発された安価なもの で、これで光周波数コムが実現できれば非常に面白い。各部分の詳細を以下に示す。
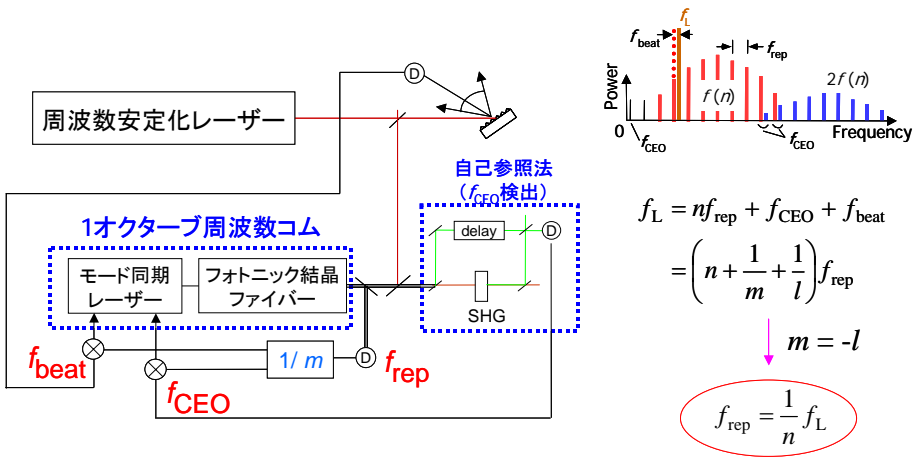

図 1 光分周器のブロックダイアグラム

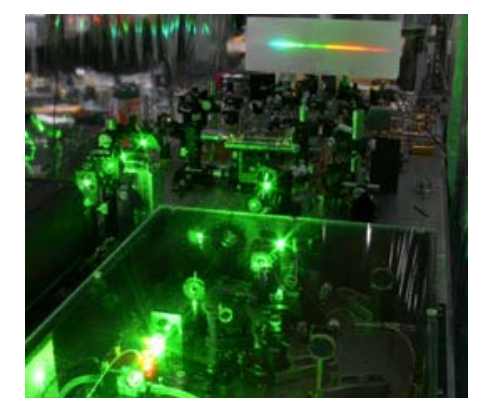

図 2 光分周器の全景

（1）1オクターブ光周波数コムを用いた光分周器

1オクターブ光周波数コムの各モ一ドの周波数は、 $f(n)=n f_{\mathrm{rep}}+f_{\mathrm{CEO}}$ と表される。ここで、 $n$ はモ 一ド次数、 $f_{\text {rep }}$ はパルス繰り返し周波数、また、 $f_{\mathrm{CEO}}$ は搬送波一包絡線オフセット周波数とよばれる。 CWレーザーとコムとのビート周波数を $f_{\text {beat }}$ とすると、レーザ一周波数 $f_{\mathrm{L}}$ は $f_{\mathrm{L}}=n f_{\mathrm{rep}}+f_{\mathrm{CEO}}+f_{\text {beat }}$ と表 せる。ここで、 $f_{\text {CEo }}$ と $f_{\text {beat }}$ を、それぞれ $f_{\text {rep }} / m 、-f_{\text {rep }} / m(m$. 整 数)にロックしたとすると、 $\mathrm{f}=n f_{\text {rep }}$ 、すなわち、レーザ一周 波数を $n$ 分周した值を $f_{\text {rep }}$ から得ることができる。

開発した光分周器のブロックダイアグラムを図 1 に、装置 全体の写真を図 2 に示す。1 オクターブ光周波数コムの出 力を低周波数側と高周波数側に分け、低周波数側の第2 高調波をとり基本波の高周波数側と重ねて $f_{\mathrm{CEO}}$ のビート信 号を検出する(自己参照法)。コムの一部を分けて、基準と なる周波数安定化レーザーとのビートを検出する。検出し

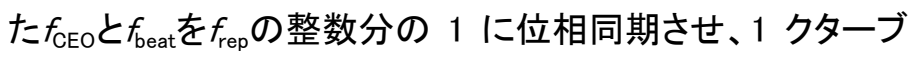
光周波数コムを光分周器として動作させる。

モ一ド同期TiSレーザーはプリズム対で分散を補償したも つとも伝統的なものを自作した。防音や結晶の冷却など改 良を進め、出力 $400 \mathrm{~mW} 、$ 、ペクトル幅 $50 \mathrm{~nm}$ と、モ一ド同期 動作の安定性を含めて市販のもの之遜色のないものが得 られた。フオトニック結晶ファイバーは試行錯誤の結果、コ ア径 $2.2 \mu \mathrm{m}$ 、及び、長さ $16 \mathrm{~cm}$ と決定した。電圧制御発振器 (VCO)の出力を 4 莪倍して $f_{\text {rep }}$ に位相同期させ、 $f_{\text {rep }} / 4$ を準
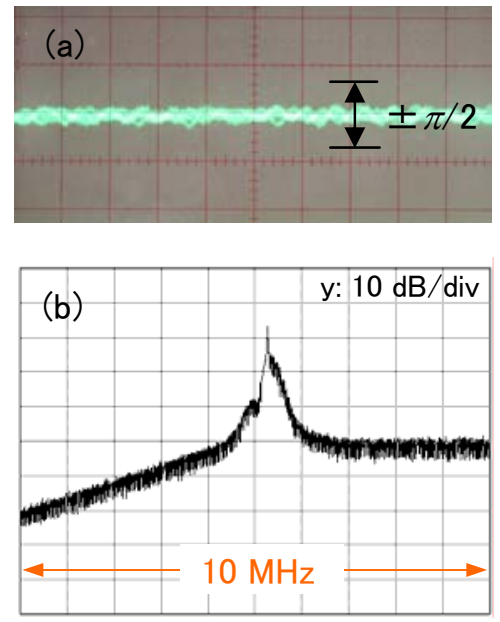

図 3 安定化レーザーへの光 周波数コムの位相同期。

(a) 誤差信号、(b) ビート信号

備し、 $f_{\text {CEO }}$ と $f_{\text {beat }}$ の位相同期に用いた。光 周波数コムの $f_{\text {rep }}$ の方がスペクトル純度 が高いので、位相同期によってVCOの 線幅が狭窄化され、制御時のVCOのス ペクトルが $f_{\text {rep }}$ と等しいことも確認された。 自己参照法により検出した $f_{\mathrm{CEO}}$ のビート 信号を、音響光学変調器でポンプ光の パワーを制御して位相同期を行った。制 御帯域幅 $400 \mathrm{kHz}$ が得られ、これは論文 で公表されている諸外国の例よりも 1 桁 広い。また、位相同期はサイクルスリッ プなく強固にかかることを確認した。

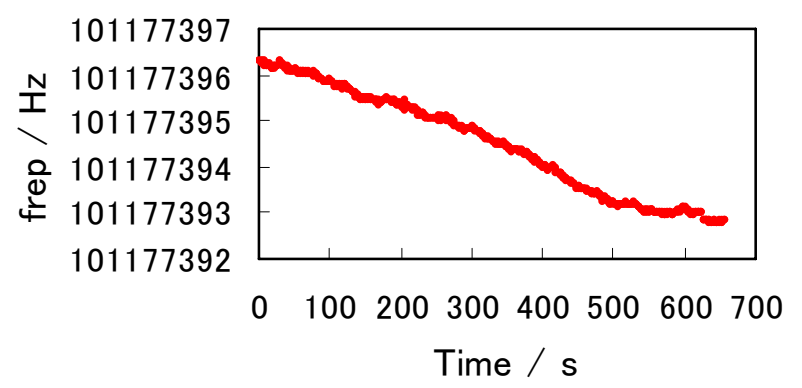

図 4 光分周器の連続動作 
周波数安定化レーザーへの光周波数コムのモードの位相同期は、応答速度は速いが伸びの 小さいピエゾ素子と、応答速度は遅いが大きく伸びるものを併用してレーザーの共振器長を制御 し実現した。2 種類用いた理由は、長時間の変動を補償し、かつ、制御帯域幅をできるだけ広くす るためである。この制御ループは光分周器の性能に直結するため、まず VCO をビ一ト信号にロッ クする、いわゆるトラッキング発振器でビ一ト信号の SN 比を改善した。また、トラッキング発振器 の出力周波数を 32 分周して原周波数に換算して $\pm 16 \pi$ までロックできるようにした。図 3 に実験結 果を示す。誤差信号は充分 $\pm \pi / 2$ 以内に収まっている。また、ビ一ト信号の中央に観測された 10 $\mathrm{dB}$ ほどの鋭いスパイクは、位相同期が達成されてパワーが集中したことを示す。

最終的に $f_{\text {beat }}$ と $f_{\text {CEO }}$ を $f_{\text {rep }} / 4$ に位相同期し光分周を達成した場合に、拜e した結果を図 4 に示す。10 分程度の連続動作に成功した。観測された周波数变動は、周波数安 定化レーザーがロックされている共振器の温度変動によるものと推定する。

（2）基準光周波数

特別に無反射コーティングを施した半導体レー ザ一を利用することなく、3 段階の線幅狭窄化を 行うことによって、キャリアへのパワー集中度の 高い狭線幅レーザーを実現した。チップ単体では 数 $10 \mathrm{MHz}$ に広がっている発振線幅を、まず、回 折光子による光帰還により $1 \mathrm{MHz}$ 程度まで、続い て低フィネス共振器へ高速制御し $10 \mathrm{kHz}$ まで狭 窄化した。光帰還後の線幅 $1 \mathrm{MHz}$ よりも充分広い $2 \mathrm{MHz}$ の制御帯域を実現できたため、キャリアへ の高いパワー集中度 $40 \mathrm{dBc}$ が得られた。そして、 低熱膨張率ガラスULE で製作された高フィネス共 振器の共鳴へ安定化し、最終的な線幅と周波数 安定度を得た。図 5 に高フィネス光共振器へ安定 化した場合の誤差信号のスペクトルを示す。レー ザー外部に置いた音響光学変調器を周波数シフ タとして用い、制御帯域幅 $170 \mathrm{kHz}$ を得た。

不確かさの小さな基準周波数を与える単一イ オンは、一価のイッテルビウムイオン $\left(\mathrm{Yb}^{+}\right)$を用 いることとした。磁場による周波数シフトが小さい 奇数同位体 171 の核スピンが $1 / 2$ と準位構造が 比較的単純で、かつ全ての光源を半導体レ一ザ 一で実現できる。緩衝気体を導入してYb+のトラッ

プを確認した。レーザー冷却光源の半導体レー ザー化のために、 2 台の半導体レ一ザーの和周 波混合を両波長ともに共鳴する光共振器内で行 う装置で $60 \mu \mathrm{W}$ の出力を、また、紫外線半導体レ 一ザ一の単一周波数発振を得た。その他、共鳴 イオン化によるイオン生成、1 $\mathrm{mm}$ サイズのトラップ の試作を行い、レーザー冷却実験を進めた。

（3）半導体レーザーによる光周波数コム

モード同期半導体レーザーとしては、光通信へ の応用を目指した波長 $1.5 \mu \mathrm{m}$ 帯のものが開発さ れている。これはモ一ド同期させるための構造を 微細加エで作りこんだ高価なもので、また、敌伤

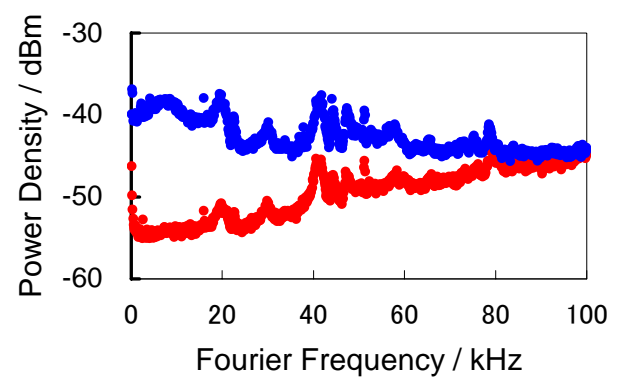

図 5 高フィネス光共振器へのロック時の 誤差信号。赤: AOM 制御あり、青: 同なし

(a)

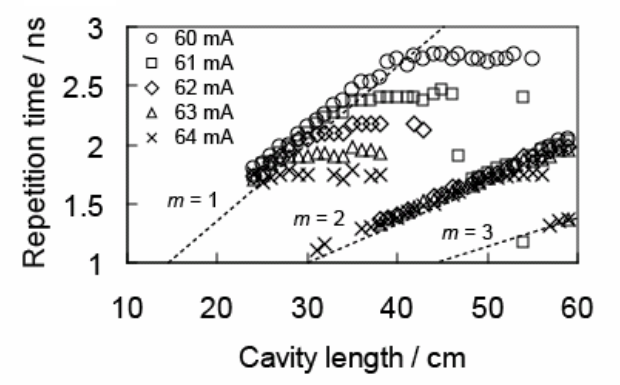

(b)

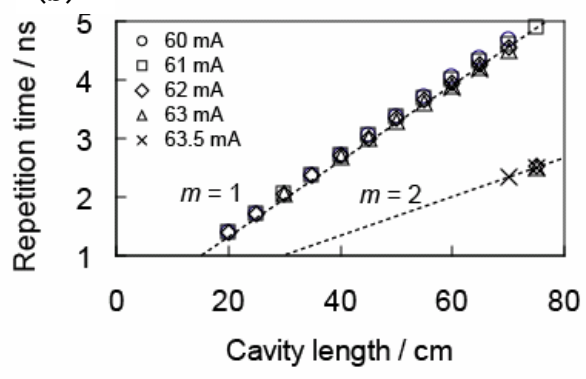

図 6 外部共振器型モ一ド同期半導体レ 一ザーの共振器長 vs パルス周期特性。 $m$ は外部共振器内のパルス数。

(a) AR コ一トなし、 (b) AR コ一トあり 
数 $10 \mathrm{GHz} ゙$ 高価なマイクロ波の部品が必要となる。本研究ではDVD読み出し用に開発された安 価な自励発振半導体レーザーの利用を追及した。

外部鏡による光帰還を行うことで、自励発振半導体レ一ザーのモ一ド同期を試みた。図 6(a)に 結果を示したように、注入電流が一定の条件では外部共振器長を長くするにしたがってパルス繰 り返し周期 $T_{\text {rep }}$ は増加し、やがて飽和した。さらに外部共振器長を長くすると共振器内に存在する パルス数が増加し、 $T_{\text {rep }}$ の増加と飽和が繰り返し観測された。飽和した值はチップ単体での $T_{\text {rep }} に$ 等しい。したがって、チップ単体の $T_{\text {rep }}$ よりも速く外部鏡から光パルスを帰還させることにより、外 部共振器で $T_{\text {rep }}$ を制御できることが分かった。

外部鏡によるモ一ド同期はある程度達成されたが、CWレーザーとのビートは全く観測できなか つた。特性を改善するために、半導体チップの出端面に無反射コ一ティングを施した。無反射コ一 テイングは研究者が所属する北野研究室で施された。図 6(b)に示すように、外部共振器長による $T_{\text {rep }}$ の制御性が大きく改善されている。また、 $f_{\text {rep }}$ のスペクトル幅は無反射コーティングなしの場合 は $10 \mathrm{kHz}$ 程度であったが、無反射コ一ティングによって $100 \mathrm{~Hz}$ まで狭くなった。1パルスあたり のエネルギーが、チップ単体で動作させた場合と同程度になる場合に性能がよく、内部構造の少 ない 10psの時間波形や各モ一ドの線幅が最も狭くなる条件 を見出した。しかし、この条件下でも、CWレーザーとのビー 卜信号は非常に限られた周波数範囲で $10 \mathrm{~dB}$ 程度のSN比 でしか観測できなかった。

ビート信号を改善するために、外部から線幅の狭いCWレ 一ザー光を注入し、モ一ド線幅の狭窄化を試みた。これによ り全スペクトル幅が $1.5 \mathrm{~nm}$ から $0.2 \mathrm{~nm}$ へ減少してしまったが、 $0.2 \mathrm{~nm}$ の範囲内であればどこでも SN 比 $30 \mathrm{~dB}$ のビート信号 が得られるようになった。得られたビート信号を図7に示す。 注入同期はもとのスペクトル幅 $1.5 \mathrm{~nm}$ 内のどこでもかかる ことが分かった。偏光を利用する方法でモ一ド同期半導体 レーザーの外部共振器モードと注入光の周波数差を検出 できることを見出し、この信号をフィードバック制御に用いて 注入同期を長時間保つことに成功した。

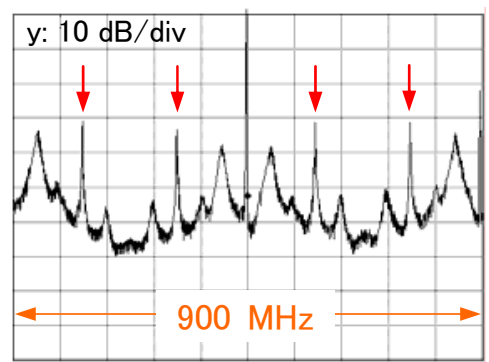

図 7 注入同期された外部共 振器型モ一ド同期半導体レー ザーと CW レーザーとのビート 信号(矢印)

5 自己評価:

主たる具体的成果は、光分周器のプロトタイプをレーザー光に位相同期させた形で完成させる ことができたこと、安価な自励発振半導体レーザーで光周波数コムを実現できる可能性を見出し たこと、である。研究開始当初はまだ実現されていなかった位相同期器型の光分周器はアメリカ の標準研究所 NIST に先を越された。しかし、特別なモ一ド同期レーザーではなく、自作のレーザ 一でも位相同期で光分周器が実現できることを示せたことは、本研究の根幹となる原理を確認で きたほかに、広く使える技術であることも証明されたと思う。（例えば、狭い線幅のレ一ザ一光を広 (波長範囲へ移す、波長の離れたレーザ一を位相同期させる)。また、本研究で実現した自励発 振半導体レーザーのモード同期は、世の中でもつとも安価なモ一ド同期レーザーである。今後ス ペクトル幅を広げることができれば、時間軸を使う計測への応用も含めて非常に面白く、楽しみな 研究の芽ができた。

商用の原子時計を全レーザーで置き換える、という最終目標に照らし合わせて考えると、イオン トラップの部分の進渉が悪かったこともあり、本研究では光分周という根幹となる原理を確認し、 光分周を半導体レ一ザーで実現するための基礎となるレ一ザ一を見出したところにとどまった。公 募時に提案した小型の全レーザーによる原子時計は、光周波数コムの応用として、基礎物理学を 除いた実用面を考えたときには、今なおもっともインパクトがあるものと確信している。最終目標に 向けた基礎を本研究期間内で固めることができたので、今後研究を発展させて当初目標を実現さ せたい。 


\section{6 研究総括の見解:}

GPS による測地精度は、人工衛星に搭載されているセシウム時計により確保されている。マイク 口波領域を基準とするこの原子時計に代えて、より高性能化が見込める光領域を基準とし、さら に、必要となるレーザーを全て半導体レ一ザーとして、低消費電力で可搬なシステムを開発するこ とを目標とした。そのための第一歩として、原子(イオン)の共鳴周波数にその発振周波数を安定 化したレーザーの周波数を、光周波数コムを使って正確に分周してマイクロ波周波数標準とする 新しい方式の原子時計を提案、開発した。

そのプロトタイプとして、モード同期チタニウムサファイヤ(TiS)レ一ザーの光パルスをフォトニッ ク結晶ファイバーに導入して、1オクターブ光周波数コムを発生させ、光分周器を実現させた。次 に市販の半導体レ一ザーを高速ロックして線幅を狭窄化した基準周波数レーザ一を構築し、安定 な単ーイッテルビウムイオンを供給するトラップの動作を確認した。更に、DC 電流を流すだけでパ ルス光を発する自励発振半導体レ一ザーのモ一ド同期を実現し、光周波数コムとして充分応用可 能であることを示した。

これらろつの要素技術を開発したことは高く評価出来る。更にこれらを統合して、所期の新しい 原理に基づく原子時計の実現が待たれる。

\section{7 主な論文等:}

論文 (2 件予定)

1) Y. Iwaki, M. Nakahara, O. Kazarsky, M. Kitano, and K. Sugiyama, "Mode-locking of a self-pulsation laser diode by external cavity configuration and its injection locking"（投稿予 定)

2) K. Sugiyama, S.N. Slyusarev, M. Misono, R. Ikuta, and M. Kitano, "Frequency control of a mode-locked titanium-sapphire laser for optical frequency divider”（投稿予定）

解説等 (3 件)

1）杉山, “モ一ド同期レーザーによる光周波数計測”, 光学, Vol. 31, No. 12, pp.871-876 (2002).

2）杉山, “マイクロ波と光周波数を結ぶ新しい周波数チェーン 一モード同期レーザーによる光 周波数計測技術一”, 日本物理学会誌, Vol. 58, No. 3, pp.175-181 (2003).

3） 杉山, “レーザーハンドブック(第 2 版） $19 \cdot 3$ 節 光周波数標準”, レーザー学会編, オーム社, 2005.

特許 (出願 2 件)

1）杉山, 中原, 北野, 岩城, “モード同期半導体レーザ”, 特願 2004-222501（出願日 2004.7.29）

2）杉山, 岩城, 北野, “モード同期半導体レーザ装置”, 特願 2005-031159（出願日 2005.2.7）

受賞 ( 1 件)

平成 15 年度文部科学大臣賞 第 28 回研究功績者 “超短パルスレーザによる光周波数計測技術 の研究”

一般国内発表 (14件) 